S

\title{
2401-W Waste Storage Building Closure Plan
}

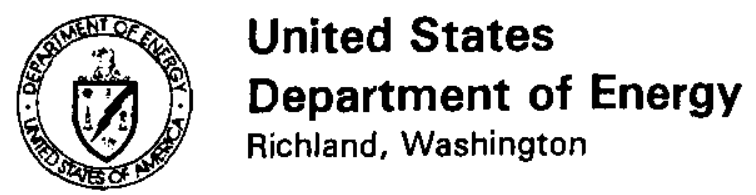




\section{INFORMATION CLEARANCE FORM}

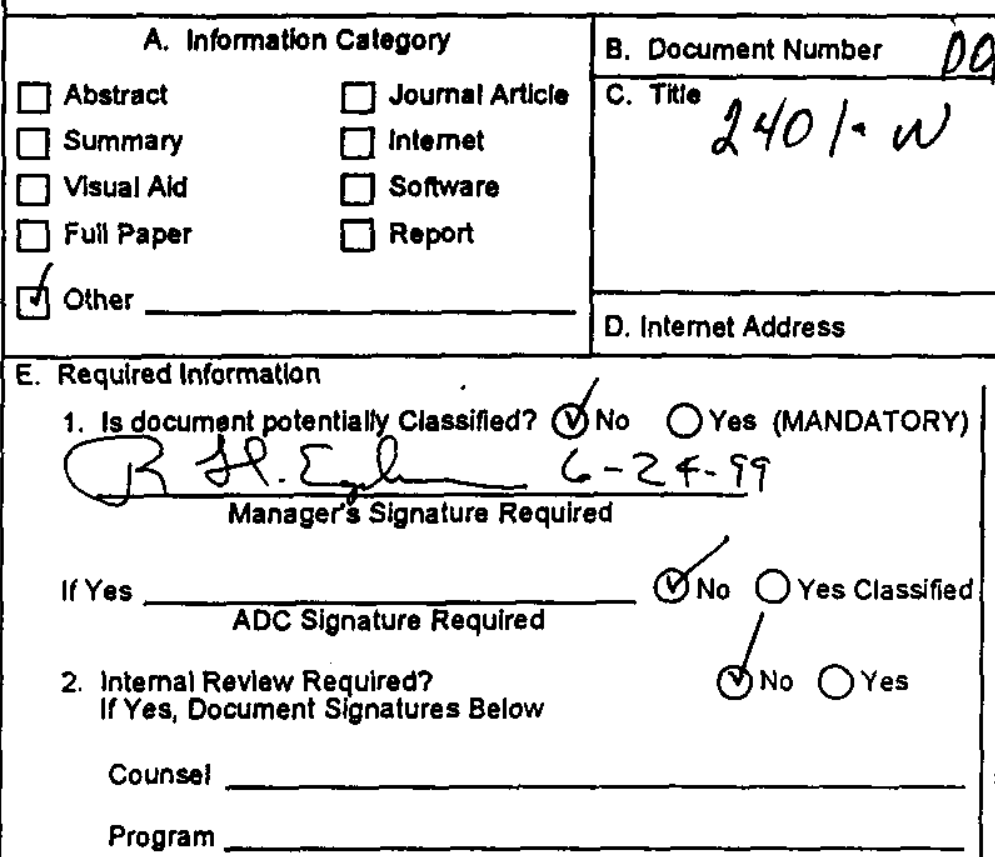

3. References in the Information are Applied Technology $\emptyset_{\text {No }}$ OYes
Export Controlled information

4. Does information Contain the Following: (MANDATORY)

a. New or Novel (Patentable) subject Matter? QNo OYes

If "Yes", Disclosure No.:

b. Information Received in Confidence, Such as Proprietary and/or Inventions? QNo OYes If "Yes", Afrix Appropriale Legends/Notices

c. Copyrights? $\bigcirc$ No $O$ Yes "Yes". Attach Permission

d. Trademarks? ONo OYes If "Yes". Identity in Document

5. Is Information requiring submission to OSTI? $O$ No $Q$ Yes

IT Yes $U C-1,30$ and $B a R$ -

6. Release Level? $Q$ Public $\bigcirc$ Limited

7. Charge Code 1016/1/CA20/19

F. Complete for a Journal Article

1. Title of Journal

G. Complete for a Presentation

1. Title for Conference or Meeting

2. Group Sponsoring

3. Date of Conference

5. Will information be Published in Proceedings? $\bigcirc$ No $\bigcirc$ Yes

4. City/State

H. Author/Requestor

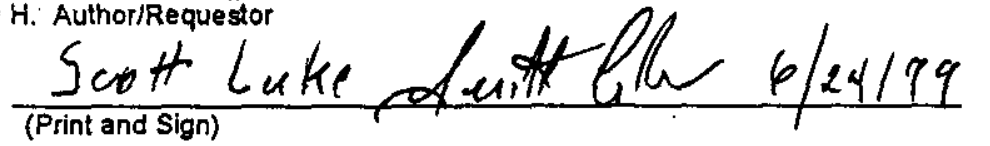

6. Will Material be Handed Out? $\bigcirc$ No $\bigcirc$ Yes

Responsibie Manager

$6-24-99$

1. Reviewers

Yes Print

General Counsel

(1) L.F. Willis

Office of External Affairs

$\square \quad N / A$

R.H. Enqe/mann

10. Co (Print and Sign)

DOE-RL

Signature

Public Y/N (It N, complete J)

Other Q L Dee DOE Transmillal Ketter
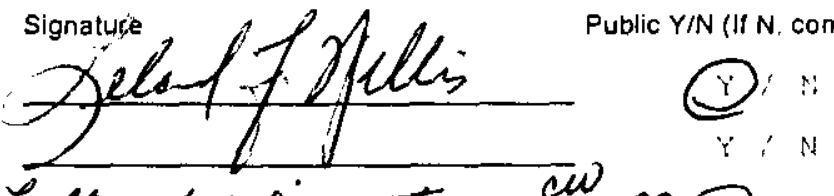

Other
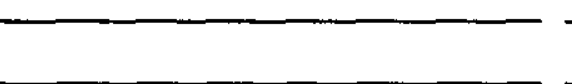

$Y / N$
$Y / N$

J. If Information Includes Sensitive Information and is not to be released to the Public indicate category below.

$\square$ Applied Technology $\square$ Protected CRADA

$\square$ Personal/Private $\square$ Export Controlled

$\square$ Proprietary $\square$ Procurement-Sensitive

$\square$ Business-Sensitive $\square$ Patentable

$\square$ Predecisional $\square$ other (Specify)

G UCNI

K. If Additional Comments, Please Attach Separate Sheet 


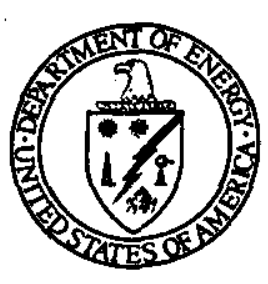

99-EAP-403

\section{Department of Energy \\ Richland Operations Office \\ P.O. Box 550 \\ Richland, Washington 99352}

\section{JUL 291999}

Mr. R. J. Julian, Acting Project Manager

Nuclear Waste Program

State of Washington

Department of Ecology

1315 West Fourth Avenue

Kennewick, Washington 99336

Dear Mr. Julian:

\section{TRANSMITTAL OF THE 2401-W WASTE STORAGE BUILDING CLOSURE PLAN}

Enclosed for State of Washington Department of Ecology (Ecology) approval is a plan for closure of the 2401-W Waste Storage Building (2401-W). The 2401-W closure activities described in this plan were completed February 9, 1999. Ecology was present during physical closure activities. Ecology approval of this closure plan is now necessary to allow final professional engineer and owner/operator certification of $2401-W$ closure in accordance with Washington Administrative Code 173-303-610 (6). Because of the extent of Ecology involvement in 2401-W closure activity planning and performance, expeditious closure plan approval is anticipated.

At the June 17, 1999, Management Monthly Interface Meeting, Ecology reaffirmed that this closure plan will be placed out for public comment. The public comment will be separate from, but may be coordinated with, the upcoming public comment period for the Hanford Facility Resource Conservation and Recovery Act Permit. The U.S. Department of Energy, Richland Operations office requests that the public comment period for the $2401-\mathrm{W}$ be initiated as soon as possible. 
Should you have any questions, please contact E. M. Bowers, of Waste Programs Division, on (509) 373-9276 or Tony McKarns, of my staff, on (509) 376-8981.

EAP:ACM

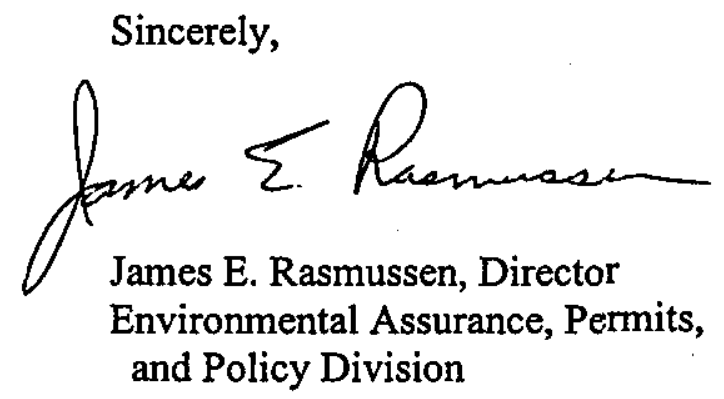

Enclosure

cc w/encl:

J. R. Wilkinson, CTUIR

W. D. Adair, FDH

J. D. Williams, FDH

Environmental Portal, LMSI

P. Sobotta, NPT

R. C. Bowman, WMH

R. H. Engelmann, WMH

S. N. Luke, WMH

J. A. Winterhalder, WMH

R. Jim, YIN 


\section{1-W Waste Storage Building Closure Plan}

Date Published

July 1999

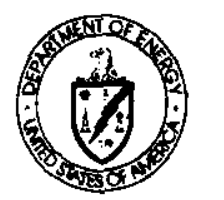

United States

Department of Energy

Richland, Washington

Approved for Public Release 


\section{RELEASE AUTHORIZATION}

\section{Document \\ DOE/RL-99-46, Rev. 0}

Number:

Document

Title:

This document, reviewed in accordance with DOE Order 241.1, "Scientific and Technical Information Management," and DOE G 241.1-1, "Guide to the Management of Scientific and Technical Information," does not contain classified or sensitive unclassified information and is:

\section{APPROVED FOR PUBLIC RELEASE}

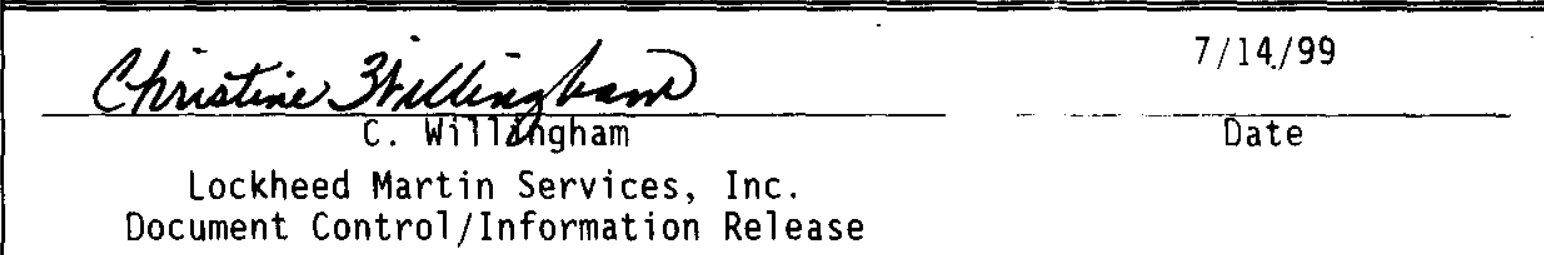

Reviewed for Applied lechnology, Business Sensitive, Classified, Copyrighted, Export Controlled, Potent, Personal/Private, Proprietary, Protected CRADA, Trademark, Unclassifieo Controlled Nuclear Information.

Trademark Disclaimer. Reference herein to any specific commercial product, process, or service by trade name, trademark, manufacturer, or otherwise, does not necessarily constitute or imply its endorsement, recomnendation, or favoring by the United States Government or any agency thereof or its contractors or subcontractors. The views and opinions of authors expressed herein do not necessarily state or reflect those of the United States Government or any agency thereof. This repor: has been reproduced from the best available copy.

Printed in the United States of America.

Available to the U.S. Department of Energy and its contractors from the U.S. Department of Energy office of Scientific and rechnical Information, P.0. Box 62, Oak Ridge, TN 37831; Telephone: 423/576-8401.

Available to the public from the U.S. Department of Comerce National Tactinical Information Service, 5285 Port Royal Road, Springfield, VA 22161; Telephone: 703/487-4650. 


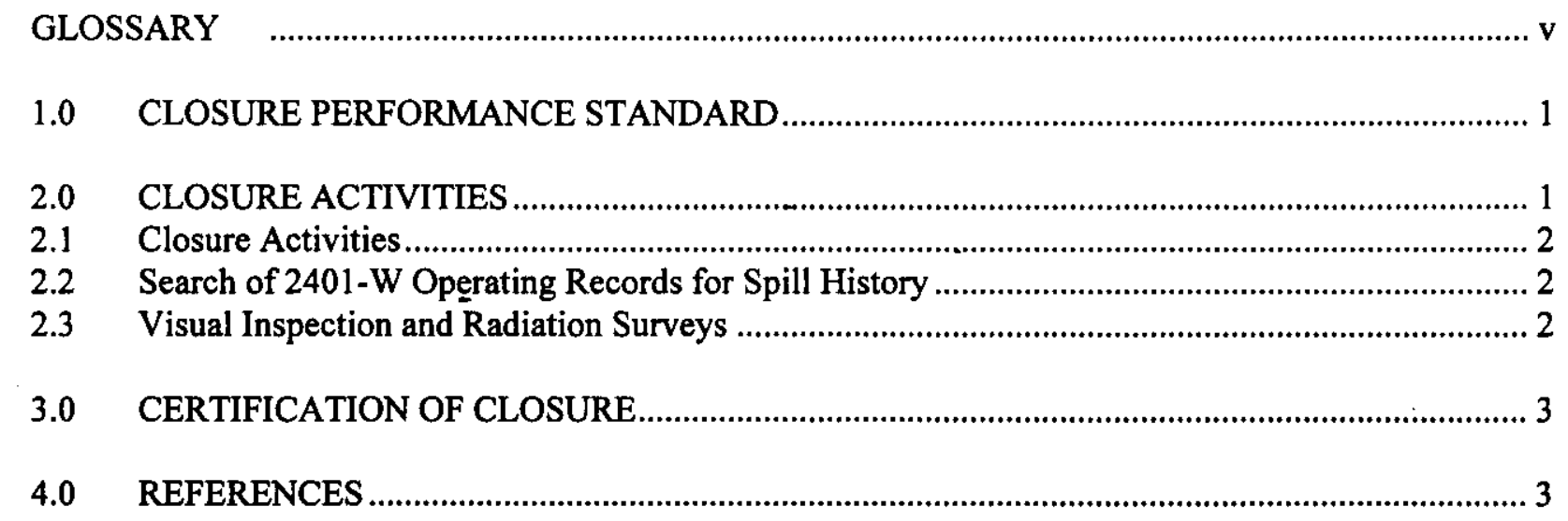

\section{APPENDICES}

A SEARCH OF CENTRAL WASTE COMPLEX OPERATIONS RECORDS FOR 2401-W WASTE STORAGE BUILDING SPILL HISTORY APP A-i

\section{FIGURE}

C PRELIMINARY PROFESSIONAL ENGINEER CLOSURE STATEMENT .................... APP C-i

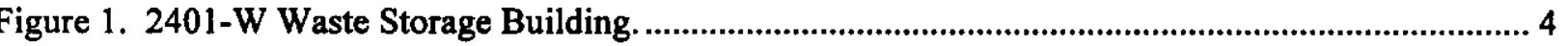


DOE/RL-99-46, Rev. 0

07/99

1

2

3

4

5

This page intentionally left blank. 
2

3

4 2401-W

5

$6 \mathrm{CWC}$

7

8 DOE-RL

9

10

11

12

13

14 RCRA

15 RMIS

16

17 TSD

18

19

20

21

\section{GLOSSARY}

2401-W Waste Storage Building

Central Waste Complex

U.S. Department of Energy, Richland Operations Office

Washington State Department of Ecology

polychlorinated biphenyl

Resource Conservation and Recovery Act of 1976

Records Management Information System

treatment, storage, and/or disposal

Washington Administrative Code 
DOE/RL-99-46, Rev. 0

07/99

This page intentionally left blank. 
This plan describes the performance standards met and closure activities conducted to achieve clean closure of the 2401-W Waste Storage Building (2401-W) (Figure 1). In August 1998, after the last waste container was removed from 2401-W, the U.S. Department of Energy, Richland Operations Office (DOE-RL) notified Washington State Department of Ecology (Ecology) in writing that the 2401-W would no longer receive waste and would be closed as a Resource Conservation and Recovery Act (RCRA) of 1976 treatment, storage, and/or disposal (TSD) unit (98-EAP-475). Pursuant to this notification, closure activities were conducted, as described in this plan, in accordance with Washington Administrative Code (WAC) 173-303-610 and completed on February 9, 1999. Ecology witnessed the closure activities. Consistent with clean closure, no postclosure activities will be necessary. Because 2401-W is a portion of the Central Waste Complex (CWC), these closure activities become the basis for removing this building from the CWC TSD unit boundary.

The 2401-W is a pre-engineered steel building with a sealed concrete floor and a 15.2-centimeter concrete curb around the perimeter of the floor. This building operated from April 1988 until August 1998 storing non-liquid containerized mixed waste. All waste storage occurred indoors. No potential existed for 2401-W operations to have impacted soil. A review of operating records and interviews with cognizant operations personnel indicated that no waste spills occurred in this building (Appendix A). After all waste containers were removed, a radiation survey of the $2401-\mathrm{W}$ floor for radiological release of the building was performed December 17, 1998, which identified no radiological contamination (Appendix B).

\subsection{CLOSURE PERFORMANCE STANDARD}

Closure of 2401-W was conducted to meet the closure performance standards of WAC 173-303-610(2). 2401-W was considered clean after the entire building floor was verified to be free of dangerous waste contamination by meeting a visual performance standard. The visual performance standard was: no obvious visual signs of potential dangerous waste contamination, except for waste staining consisting of light shadows, slight streaks, or minor discoloration. Achievement of this standard was verified by visual inspections. Any floor area not meeting this standard would have required removal of the indication, a radiation survey, and re-inspection of the removal area.

Because only mixed waste was stored in $2401-\mathrm{W}$, the presence of radionuclides was considered an indicator parameter for the presence of the dangerous component of the mixed waste. Locations not meeting the visual performance standard, along with floor areas randomly selected during visual inspections, also were required to meet a radiological performance standard. The radiological performance standard, where applied, was: no measurable amount of radiological contamination above background levels. Radiological background was established as described in Appendix B. Achievement of this standard was verified by radiation surveys (Appendix B). Any location that exceeded radiological background would have required removal of the indication, visual inspection, and resurvey.

\subsection{CLOSURE ACTIVITIES}

44 This section identifies the closure activities performed to verify $2401-\mathrm{W}$ clean closure conditions. If the 45 record review (Section 2.2) had identified waste spills or if visual or radiological indications had been 46 identified during inspections and surveys (Section 2.3), the floor would have been decontaminated to 
remove the indications and the removal area re-inspected and resurveyed. However, because no visual or radiological indications were identified (Appendix B), no decontamination or further activities (e.g., soil or structure sampling) were considered necessary to verify clean closure.

\subsection{Closure Activities}

By the time of closure, all waste containers had been removed from the 2401-W and no waste handling equipment remained in the building. Closure activities performed to verify $2401-\mathrm{W}$ clean closure conditions consisted of the following:

- Reviewed documents and interviewed personnel to determine spill history (Appendix A)

- Visually inspected building floor

- Performed radiation survey of randomly selected floor locations

- Documented visual inspections and radiation surveys on an inspection checklist (Appendix B)

- Obtained preliminary professional engineer's (PE) statement that closure activities were completed in accordance with this closure plan (Appendix C).

After the closure plan is approved by Ecology, closure certification will be submitted to Ecology in accordance with WAC 173-303-610(6) and the CWC TSD unit boundary will be modified to exclude 2401-W.

\subsection{Search of 2401-W Operating Records for Spill History}

2401-W operating records were reviewed to identify whether mixed waste spills had occurred. The records included operations logbooks, RCRA weekly inspection records, and 'offnormal' event reports. Former and current cognizant operations personnel also were interviewed. Sufficient operating records and reports exist and cognizant personnel were available to establish a complete history of 2401-W operations. The operating history indicated that no mixed waste spills occurred in 2401-W (Appendix A).

\subsection{Visual Inspection and Radiation Surveys}

Visual inspection of the 2401-W floor and loading ramp was performed February 9, 1999. The inspections were documented on the radiation survey and visual inspection checklist (Appendix B). No visual indications of potential dangerous waste contamination were identified that required removal or a follow-up radiation survey. During the inspections, one floor area located in grid D-1 was cleaned with damp rags to remove dirt that potentially could have masked a visual or radiological indication (Appendix B). No visual or radiological indication was identified by the visual inspection and radiation survey of the cleaned area.

A radiation survey of randomly selected areas of the floor, the loading ramp, and of the dirt removal area was performed at the time of the visual inspections (Appendix B). The 'direct survey' and 'large area wipe' were the radiation survey methods used and were performed as described in Appendix B. No surveyed area showed measurable radiological levels above background levels. 


\subsection{CERTIFICATION OF CLOSURE}

2 After completing closure activities, a preliminary PE statement (Appendix C) that the activities were 3 performed in accordance with technical specifications of the closure plan was prepared and provided to 4 Ecology (99-EAP-202). After approval of this closure plan by Ecology, final 2401-W closure 5 certification will be prepared in accordance with WAC 173-303-610(6), transmitted to Ecology, and 6 placed in the Administrative Record.

7

8

\subsection{REFERENCES}

98-EAP-475, Letter to L. J. Cusack, Ecology from James E. Rasmussen, DOE-RL, "Notification of Intent to Close the 2401-W Waste Storage Building", August 28, 1998.

99-EAP-202, Letter to Moses N. Jaraysi, Ecology from J. E. Rasmussen, DOE-RL, "Closure of the 2401-W Waste Storage Building", March 29, 1999.

DOE/RL-91-17, Hanford Facility Dangerous Waste Permit Application, Central Waste Complex, Rev. 1, U.S. Department of Energy, Richland Operations Office, Richland, Washington. 


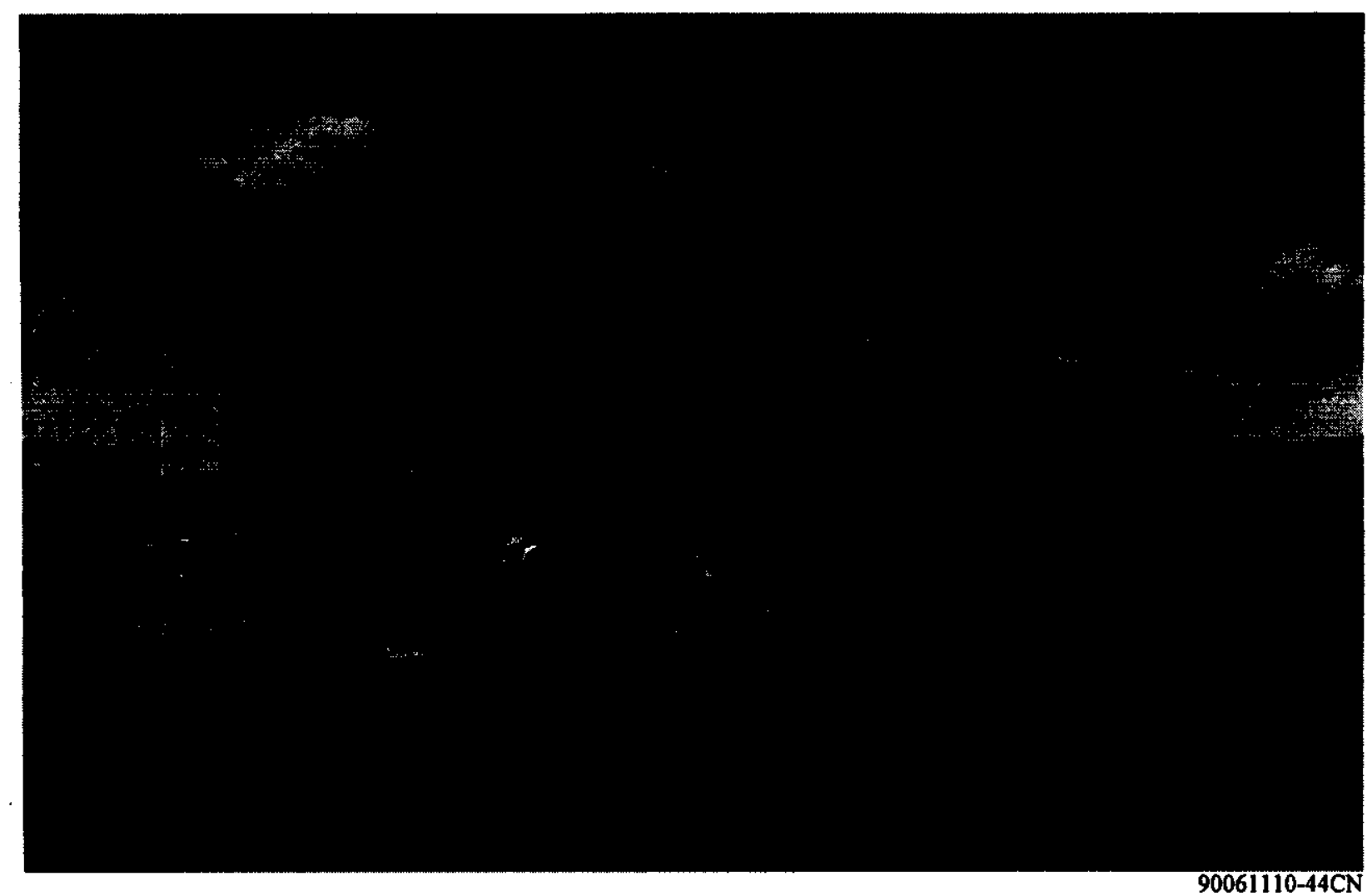

Figure 1. 2401-W Waste Storage Building. 


\section{APPENDIX A}

3

SEARCH OF CENTRAL WASTE COMPLEX OPERATIONS RECORDS FOR 2401-W WASTE STORAGE BUILDING SPILL HISTORY 
DOE/RL-99-46, Rev. 0

07/99

This page intentionally left blank. 


\section{SEARCH OF CENTRAL WASTE COMPLEX OPERATING RECORDS FOR 2401-W WASTE STORAGE BUILDING SPILL HISTORY}

For closure of CWC, or any portion of CWC, operating records are reviewed and cognizant operations personnel interviewed to obtain spill history for the portion(s) undergoing closure (DOE/RL-91-17, Rev. 1, Chapter 11.0, Section 11.1.2). Spill history is necessary to help determine the need for and extent of decontamination necessary for clean closure. Closure of 2401-W , a portion of CWC, necessitated such activities to identify dangerous waste spills (if any) to surfaces of the building. As activities required by the approved closure plan, the operating records review and personnel interviews used to establish 2401-W spill history were intended to be sufficiently diligent to allow PE certification of the activities and for use as a credible basis in establishing conclusive $2401-W$ spill history. Certification by a registered professional engineer (PE) will be obtained.

The records review entailed a page by page review of all available records related to 2401 -W operations. The records reviewed to satisfy this requirement included operations logbooks, RCRA weekly inspection records, and a search for 'offnormal' event reports. Also as a requirement, former and current cognizant 2401-W operations personnel were interviewed. Because closure of the 2401-W represents partial closure of CWC, the results of the document review and of personnel interviews will become the basis for removal of the 2401-W from the CWC TSD unit boundary by revision of the CWC Part A, Form 3, and Part $B$ permit applications.

Operating documents and records currently are located as follows.

- Occurrence reports are located at MO 278.

- The most current CWC operating logbook is located in MO-288.

- Weekly inspection records before 1997 were retrieved from Records Management Information System (RMIS).

- All other records were found in the CWC regulatory file located at MO 720.

\section{Background Information}

In April 1988, waste storage operations began at the 2401-W. Weekly inspection records for 2401-W show that for all or most of the first 4 months of operations (until 08/03/88) little or no waste was stored in the building. This building was designed to meet all the requirements for storage of mixed waste (DOE/RL 91-17) in metal boxes or drums. Only containers in good condition were accepted. Transuranic waste was double contained. Where incidental free liquids were known to exist, containers were required to be packed with two times the calculated quantity of absorbent required to absorb the entire quantity of free liquids

Operations logbooks document the quantity of waste received at this unit and how waste was managed. These logbooks confirm that this building managed small quantities of specialized waste. When stored, the waste containers were seldom moved and remained in good condition after waste acceptance. Consequently, there was little potential for spills from defective containers, damaged or leaking containers due to container mishandling, or container degradation from weathering. The waste typically remained as stored until all waste finally was removed in August 1998 in preparation for building closure. 


\section{Records Review and Personnel Interviews}

The event fact sheets, located in MO 278, and occurrence reports relating to CWC operations were reviewed. No event fact sheets or occurrence reports were generated for the $2401-\mathrm{W}$.

The CWC daily operating logbooks represent the most comprehensive, first-hand record of operations and cover the entire period of $2401-W$ operations. There are no logs dedicated solely to operations of the 2401-W. Except as noted, handwritten logbooks were available for review from 1988 to present. From the beginning of operations until October 1990, daily operations for all solid waste units (CWC, 224-T Transuranic Waste Storage and Assay Facility, 616 Nonradioactive Dangerous Waste Storage Facility, and Low-Level Burial Grounds) were consolidated into handwritten logbooks identified as sequentially numbered daily operating records (DOR). From February 1991 to the present, a separate logbook has been kept for each unit. The practice of uniquely numbering each operating logbook was discontinued in October 1996.

Handwritten logbooks were not available for review for October 1990 until February 1991, which was the transition period to the new, unit-specific logbooks. During this period, the DORs consisted of typewritten reports summarizing operators' handwritten pocket notebooks. These reports were generated daily and were an authoritative representation of normal daily occurrences and of significant events (e.g., waste shipments and process upsets, such as spills). Typewritten reports were available for the period of operations for which the daily handwritten logs were not available.

The following logbooks and reports were reviewed for evidence of spills. Although mention is made in logbooks of cleanup of rainwater and snowmelt that entered under the building's rollup doors, no mention is made of dangerous waste spills or container breaches that could have lead to spills.

- Logbook - SW-DOR-00003 (10/88 - 9/89)

- Logbook - SW-DOR-00004 (9/89 - 10/90)

- Report - SW-DOR-00005 (9/90 - 9/90, September only)

- Report - SW-DOR-00006 (10/90-9/91, Part 1 of 3)

- Logbook - SW-CWC-00001 (2/91-2/93)

- Logbook - SW-CWC-00002 (2/93-8/93)

- Logbook - SW-CWC-00003 (9/93-1/94)

- Logbook - SW-CWC-00004 (1/94-5/94)

- Logbook - SW-CWC-00005 (5/94-9/95)

- Logbook - SW-CWC-00006 (10/95-10/96)

- Logbook (10/96-6/97)

- Logbook (6/97-8/97)

- Logbook (8/97-4/98)

- Logbook (4/98-12/98)

- Logbook (12/98-present).

Weekly RCRA Inspections. Weekly inspections of 2401-W surfaces and of stored containers were documented on checklists. Checklist inspection parameters included unit cleanliness, storage surface integrity, container integrity, and indication of spills. The checklists were complete for the period of operations. Weekly inspection checklists do not indicate any leaking, damaged, or breached waste containers or evidence of spills on containment surfaces near containers. However, the inspection for September 7, 1988 identified that a "small amount" of oil had been spilled to the floor from a forklift by 
1 the east door but had been cleaned up immediately. The following weekly inspection records were

2 reviewed for evidence of spills.

3

- June 1988 through December 1997 (retrieved from RMIS):

- SW-2401-W-1989

- SW-2401-W-1990

- SW-2401-W-1991

- SW-2401-W-1992

- SW-2401-W-1993

- SW-2401-W-1994

- SW-2401-W-1995

- SW-2401-W-1996.

- Weekly Inspection checklists for January 1997 to present (CWC regulatory file):

- No log number

$(1 / 97-3 / 97)$

- No log number

$(4 / 97-6 / 97)$

- No log number

$(7 / 97-9 / 97)$

- No log number

$(10 / 97-12 / 97)$

- No log number

$(1 / 98-3 / 98)$

- No log number

$(4 / 98-6 / 98)$

- No log number

$(7 / 98-9 / 98)$

- No log number

(9/98-present).

Operations Personnel Interviews. Cognizant current and former CWC operators and operations managers were interviewed for direct or indirect knowledge of waste spills or container breaches in the 2401-W. Management and hands-on operators for the entire period of 2401-W operations were interviewed. All personnel interviewed were asked the following question: "Are you aware of any waste spills, leaks, or waste container breaches in the 2401-W Building?"

\section{Operations managers interviewed.}

- The CWC Operations manager from 1987 to November 1990 and again from June 1997 to the present, was interviewed in person October 28, 1998. He responded that during his tenure as operations manger, no spills or container breaches occurred in the 2401-W Building.

- The CWC Operations manager from November 1990 to March 1993 was interviewed in person October 28, 1998. He responded that during his tenure as operations manager, no spills or container breaches occurred in the 2401-W Building.

- The CWC Operations supervisor from March 1993 to June 1997 responded electronically to the potential for leaks at $2401-W$ on December 10,1998 . She stated that during her tenure as operations manager, no spills or container breaches occurred in the 2401-W Building. 


\section{Cognizant operators.}

- A CWC Nuclear Process Operator (NPO) from 1988 to the present was interviewed in person

. October 29,1998 . He stated there had not been any spills or container breaches since the beginning of 2401-W operations.

- A CWC NPO from before 1988 to the present was interviewed October 28, 1998 by telephone. He indicated that no spills or container breaches occurred since the beginning of $2401-\mathrm{W}$ operations.

- A CWC NPO from before 1988 to the present was interviewed December 10, 1998 by telephone. He indicated that that no spills or container breaches occurred since the beginning of 2401-W operations.

\section{Results of Records Review and Personnel Interviews}

The operating records review and personnel interviews used to establish 2401-W spill history were sufficiently diligent to allow PE certification of these closure activities and for use as a credible basis in establishing conclusive $2401-\mathrm{W}$ spill history.

Sufficient operating records and reports exist, and cognizant personnel were available for interview, to establish that an authoritative and complete record of $2401-W$ operations exists.

Operating records and reports and personnel interviews identify no spills to $2401-\mathrm{W}$ surfaces. No occurrence reports were written to document releases to the $2401-W$. No mention is made in daily operations logs or in weekly inspection reports of waste spills to 2401-W floors. All personnel interviewed indicated that to their direct or indirect knowledge, no waste leaks or container breaches occurred that could have contaminated 2401-W surfaces. Further, stringent waste acceptance criteria for containers, the relatively small quantity of waste managed at this unit, the minimal level of container handling once waste was stored, and the fact that degradation of containers by weathering was not a factor, greatly minimized the potential for spills.

From the records, reports, and interviews documented herein, it reasonably can be concluded that no dangerous waste spills occurred to the floors of the 2401-W. 
DOE/RL-99-46, Rev. 0

$07 / 99$

1

2

3

4

\section{APPENDIX B}

RADIATION SURVEY AND VISUAL INSPECTION CHECKLIST 
DOE/RL-99-46, Rev. 0

07/99

This page intentionally left blank. 


\section{RADIATION SURVEY AND VISUAL INSPECTION CHECKIIST FOR CENTRAL WASTE COMPLEX CLOSURE ACTIVITLES}

Instructions for completing this checklist are on pages 3 and 4.

1. Structure undergoing closure: 2401-W Storage Building (Floor Plan, page 5)

2. Conponents/materials being inspected: Epoxy-conted concrete floor

3. Structure spill history:

(1) The document reviews and personnel interviews required for deternuining spill history are complete.

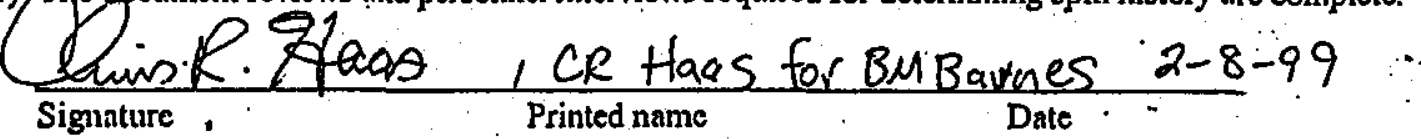

(2) Spill(s) are identified on building floorplan. NA INA per step 3(1) if no documented spills] 1. (Initial/date)

4. Assigned visunl inspectors and radintion survey personnel:

(1) Visual inspector(s);

Name: 21 f a f rieid D.E. Paghan Ir DiR.

Assigning mannger: Clh SM:<smiles>C=C(C)CCCCCC</smiles>

(2) Radiation survey personnel: Name: Ahanda Stanper Rogex Holcomise Emfly Millikin

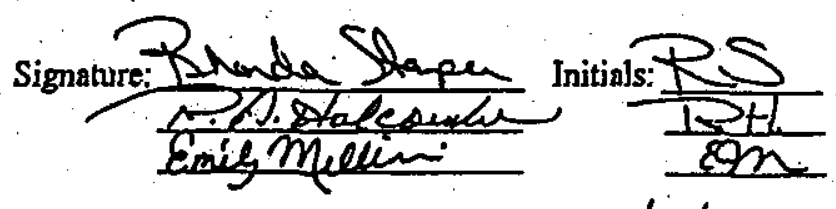

Assigning nanager: $\frac{\text { Ji Miller-eg Migukin for }}{\text { Signature }}$ $\frac{Q / 9 / 99}{\text { Date }}$

\section{Initial Radiation Survey}

(1) Initial radiation survey(s) completed. (Initial/date) PS 12.999

(2) Radiological performance standard met for all surveyed locations. (Yes or No) yes (Initial/date) $\mathrm{R} S 1-2-9-99$. If No, do step 7 .

(3) Radiation survey comments (if any): Survey of Random Cleanup areas performed no contanination was found.

BS/2.9.99 (Initial/date) 


\section{Initial Visual Inspection}

(1) Initial visual inspection of all locations is complete. (Initial/datc) $0 \varepsilon \rho / 2-9.99$

(2) Visual performance standard met for all locations. (Yes or No) yes (Initial/date) . $\mathrm{ASP} / 2.9-99$. If No, do step 7.

(3) Visual inspection comments (if any): Cleaned stsin in section D and Re seriveyed akes. . DsP /2-?-99 (Initial/date)

7. Decontamination and Verification $n / A$ [NA if Steps $5(2)$ and $6(2)$ are marked Yes]

(1) Decortamination method used:

\begin{tabular}{ll}
\hline 1 \\
\hline 1
\end{tabular}

(2) Commentș on decontamination (if any):

\begin{tabular}{ll}
\hline \\
\hline$/$ \\
\hline
\end{tabular}

(3) Decontamination is complete.

$$
1
$$

(Initial/date)

Note: Decontamination waste will be collected, designated, and disposed of accordingly.

(4) Verification of visual and radiological performance standards for decontaminated locations.

(a) Radiation survey complete and radiological performance standards met at all decontaminated locations. (InitiaVdate)

(b) Visual inspection complete and visual performance standard met for all decontaminated locations. (Initial/date)

8. Additional comments (if any): Dene

O\&P/2.9:99 (Initial/date)

9. The checklist is complete. $D<P / 2-9-92$ (Initial/date)

Note: Fonward the completed checklist to the CWC Environmental Compliance Officer for placemient in the CWC reguilatory file. 


\section{RADIATION SURVEY AND VISUAL INSPECTION CHECKLIST FOR CENTRAL WASTE COMPLEX CLOSURE ACTIVITIES}

\section{Instructions for Completion}

1. Identify the CWC structure undergoing closure.

2. Identify the portion of the structure undergoing closure and the type of material (e.g., coated concrete floor).

3. (1) An assigned inspector [step 4(1)] or other cognizant Solid Waste personnel will sign this step when document reviews and personnel interviews required by the closure plan to establish spill history for the locations identified at steps 1 and 2 are complete and documented. If no spills occurred, mark

- step 3(2)NA.

(2) If this step is not marked.NA, an assigned inspector will sign off that spill history documentation completed for step $3(1)$ has been reviewed and the location of all documented spills is shown on the gridded floor map (page - 5) for inspection.

4. (1) and (2). The nppropriate manager will sign off this step when visual inspection and radiation survey personnel are assigned. Inspection and survey personnel will sign and print their name and enter their initials.

5. (1) Initinl radiation surves(s) are anticipated to occur at the time of the vistual inspections. Inspector(s) will sign off that all randomly selected locations ind all visual indications [step $6(2)$ ] have .undergone initial radiation survcy as described below and all surveyed locations and the survey method used are documented on attached floor plan.

Performing the radiation survey: .

- Establishing radiological background. Radiological background will be established using onsite methods and good health physics practices. The health plysics teclunician will enter the building, turn on the instrument, set thic range switch to the Jowest range, and allow a 10 -second. wvarm up. For the Geiger-Mucller portable survey instrument, the maximum background is limited to 150 counts per minute. Instrument efficiency is based on the instrument being held within $1 / 4 "$ of the surface. For the portable alpha meter, 3 counts per minute will allow efficient operation.

- Rndiation survey methods. Radiation surves(s) will consist of using appropriate hand-held instrumentation and/or of smears that will be read with stationary equipment located at MO-438. Large aren wipe (LAW), technical smear.(TS), static measurenent (SM), and scan measurement (Scan) will be used as considered necessary. LAWs cntail wipedown of an area approximately 300 square centimeters by hand with a swipe media. The surface is counted with the portable instrument. A TS entails taking wipes of an area approximately 100 square centineters with the swipe media which is counted by stationary equipment located as MO-438. SMs entail holding the probe within $1 / 4$ inch of the area to be surveyed and holding at that location for 10 to 20 seconds. Scans entail holding the probe $1 / / 4$ inch from the surface and scanning a location at a travel speed of approximately 2 inches per second. 
(2) The radiological performance standard is 'no measurable amounts of radiological contamination above background levels'. Any spot, area, or location that exceeds radiological background will be considered a radiological indication that will be identified on the attached floor plan. The TS method will be used to identify the extent of radiological contamination.

(3) Enter any comments regarding the radiation surrey:

Note: A current radiological release for the entire $2401-W$ Storage Building is documented on Radiological Survey Report, Number SW 243073 (Attachment 1).

6. (1) Initial visual inspections will be considered complete and this slep signed off when all locations identified in steps 1 and 2 and on the floor plan (page 5) have been inspected for achicvement of the visual performance standard.

(2) The dangerous vaste performance standard is 'no obvious visunl signs of potential dangerous waste contamination'. Surfaces must be free of indications of dangerous waste, except for residual waste stains consisting of light shadows, slight streaks, or minor discoloration. A visual indication is any aren that does not meet this standard. Notc: This visual standard is inore stringent than the $40 \mathrm{CRF} 268.45$ 'clean debris surface' standard for clean closure of containment structures recommended in Ecology's Guddance for Clean Closure of Dangerous Waste Facilities (Publication \#04-111) that allows resichal staining and some waste to remain after closure.

(3) Enter any conuments regarding the visual inspections.<smiles>[14CH3][14CH3]</smiles>

. (1) Surfnce(s) will be decontanininated by being washed, wiped, or scrubbed by hand using damp cloths, paper towels, or brashes and, as necessary, a nourcgulated cleaner or detergent. The " decontamination method and materials used will be entered.

(2) Enter nny comments regarding decontamination.

(3) This step is signed off when all locntions shown as requiring decontamination by steps 5(2) and 6(2) are decontaminated.

(4) (a) Sign off step after all decontaminated locations are surveyed using the TS method (unless survey personnel identify a more appropriate survey method) and the radiological performance standard described in step 5(2) is met.

(b) Sign off step when all decontaminated location(s) have been visually inspected and the visual performance standard described in step $6(2)$ is met.

Note: Decontamination waste will be collected, designated, and disposed of accordingly.

8. Enter any conments not previously entered.

9. This step is signed off when inspector(s) have reviewed the checklist and all steps are complete and verified, and all visual and radiological indications identified on the floor plan (page S) are dispositioned. Note: The completed checklist is to be forstarded to the CWC Environmental Compliance Officer for placement in the CWV regulatory file. 


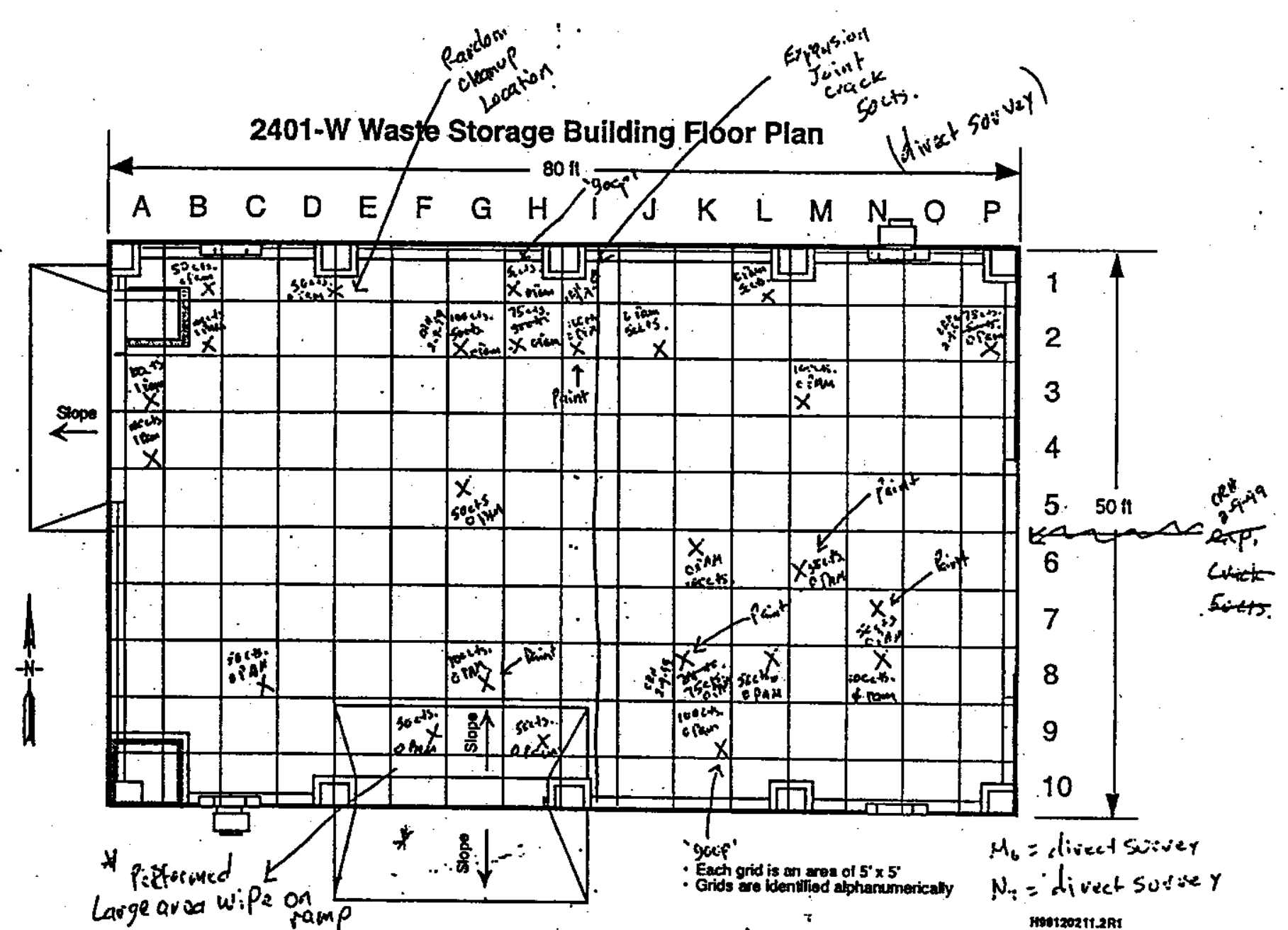
Laoge arva wipe or ramp $B_{1}=$ direct survey $D_{1}, E_{1}=$ divect survey $H_{1}=$ divect soivey $L_{1}=$ direct sorvey $P_{2}=$ divect sirvey
$V_{5}=$ dirzat survay

$L_{g}=$ direct suiviy $J_{2}=$ divect survey $C_{2}=$ divent Suiviey $S_{2}=$ divact suevey $M_{1}=$ direct sorvey
$N_{g}=$ direct sudey $C_{3}=$ Airect survey. $k_{g}=$ diract Survey
$\mathrm{Fq}_{q}, \mathrm{H}_{q}=$ direct Survey $A_{3}, A_{-1}=$ direct Survey $\mathrm{L}_{3}=$ direct $5 J=$ wey $G_{s}=$ divect sirvey $I_{2}=$ dienet Survey 


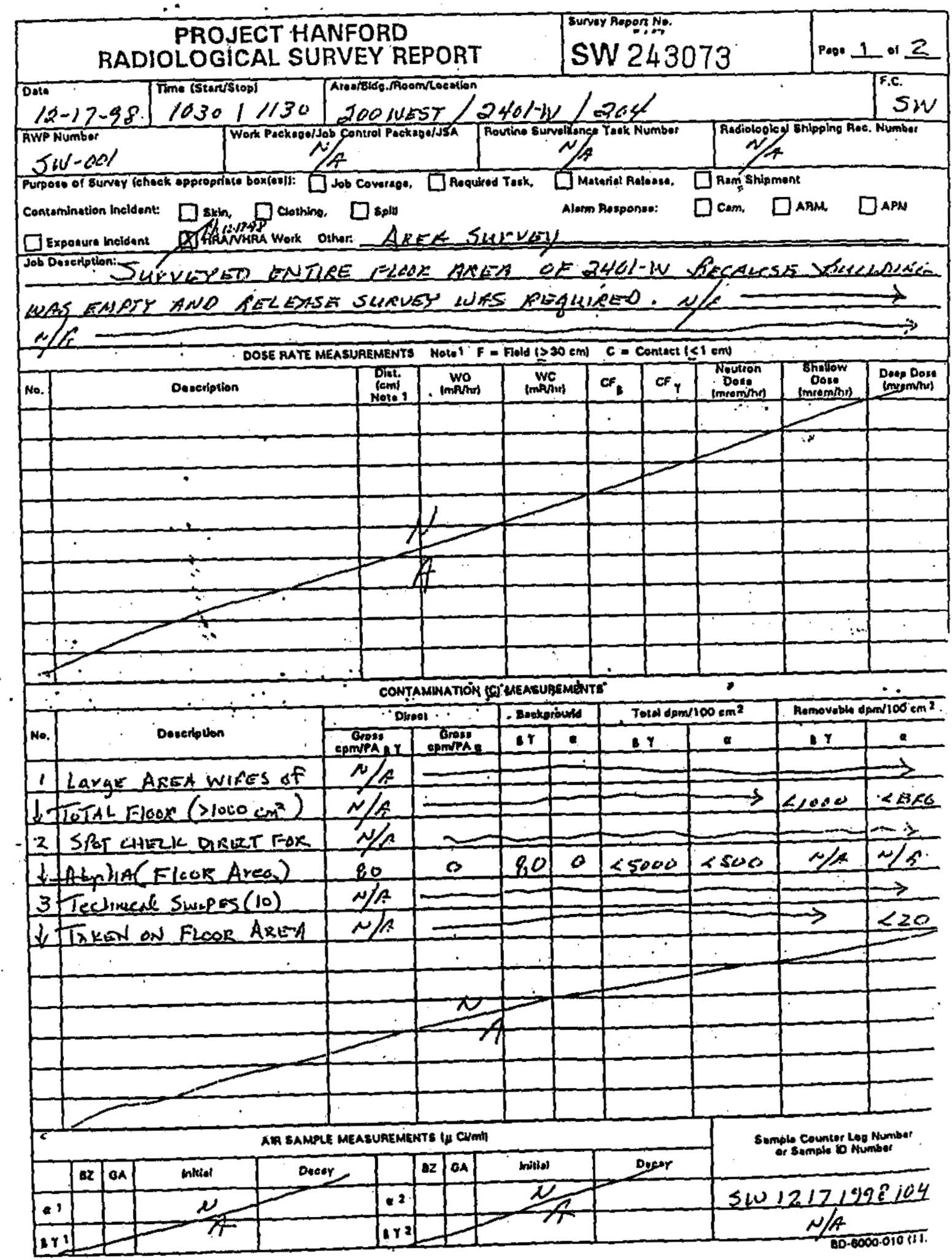




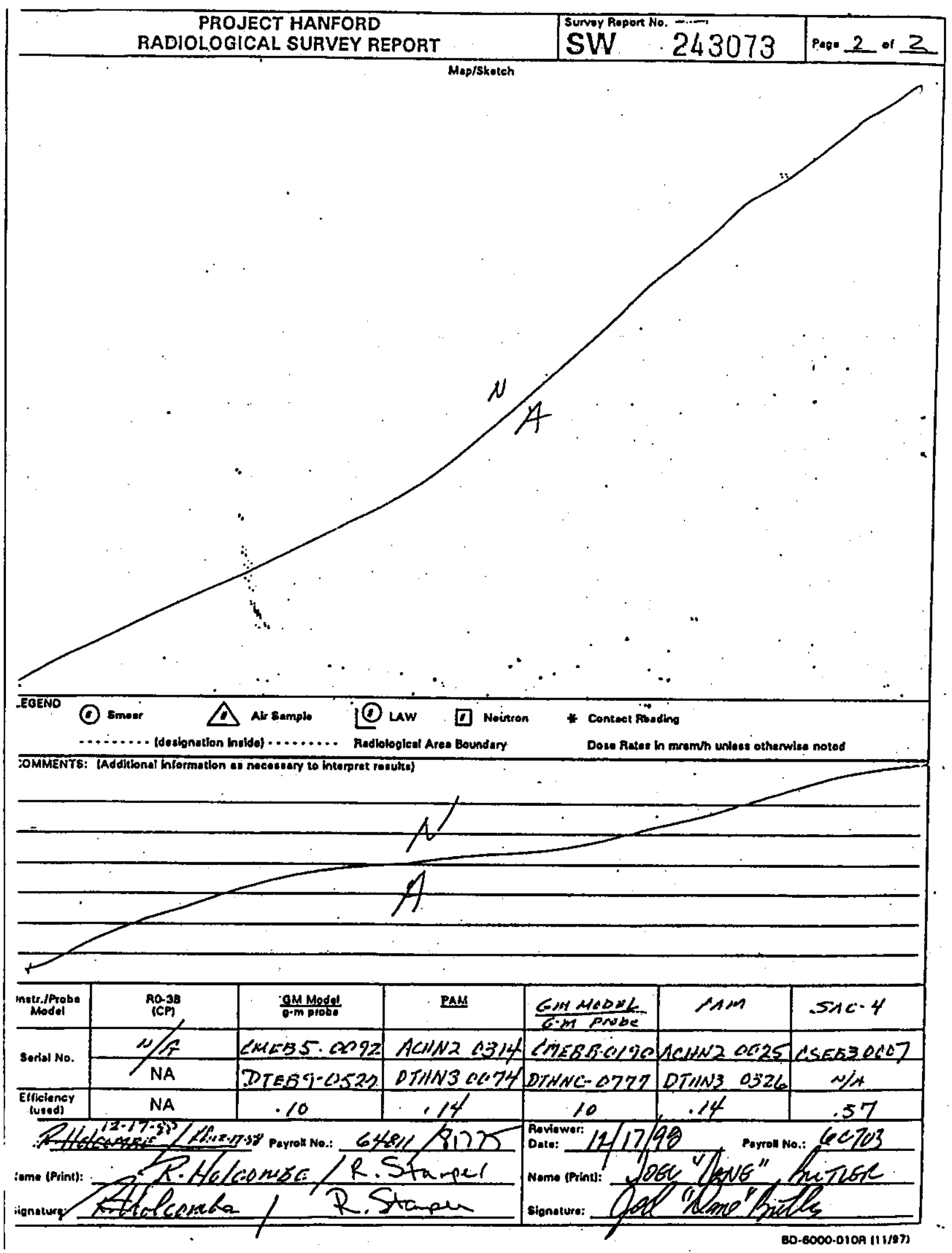


DOE/RL-99-46, Rev. 0

07/99

This page intentionally left blank. 
DOE/RL-99-46, Rev. 0

$07 / 99$

3

\section{APPENDIX C}

PRELIMINARY PROFESSIONAL ENGINEER CLOSURE STATEMENT 
This page intentionally left blank. 


\section{PRELIMINARY PROFESSIONAL ENGINEER'S STATEMENT FOR CLOSURE OF THE 2401W STORAGE BUILDING}

Chapter 11 of the "Hanford Facility Dangerous Waste Permit Application" (DOE/RL-91-17 Rev 1) gives the closure requirements for the Central Waste Complex Storage Facilities (CWC). The document is in the process of approval by the Washington State Department of Ecology. Closure activities based on the current document have been completed.

Periodic site visits, phone conversations and document reviews were conducted to observe and document the closure activities. Each inspection activity was recorded on the Inspection Checklist for CWC Closure Activities. My field trip observations are recorded on Field Trip Report forms.

All requirements for closure activities stipulated by the current closure documents have been met. The periodic inspections including the final inspection revealed no discrepancies.

The final certification of closure statement will be issued upon Ecology approval of the closure document.

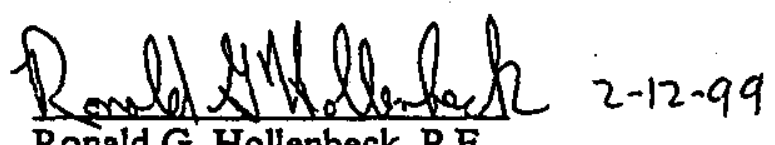

Ronald G. Hollenbeck, P.E.

Washington \#23750

Fluor Daniel Northwest Inc. 
This page intentionally left blank. 


\section{DISTRIBUTION}

MSIN

Washington State Department of Ecology

T. A. Wooley

B5-18

J. Wilkinson

Confederated Tribes of the Umatilla Indian Nation

P. O. Box 638

Pendleton, Oregon 97801

D. Powaukee

Nez Perce Tribe

P. O. Box 365

Lapwai, Idaho 93540

R. Jim, Manager

Environmental Restoration/Waste Management Program Yakama Indian Nation P. O. Box 151

Toppenish, Washington 98948

U.S. Department of Energy, Richland Operations Office

E. M. Bowers

S7-55

A. C. McKarns

A5-15

G. L. Sinton

S7-55

Public Reading Room

H2-53

Fluor Daniel Hanford. Inc.

A. G. Miskho

H6-23

F. A. Ruck III

H6-23

J. D. Williams

H6-06

Pacific Northwest National Laboratory

Hanford Technical Library

P8-55

Waste Management Federal Services Hanford, Inc.

M. D. Aichele

T4-04

B. M. Barnes

T4-04

R. C. Bowman

H6-24

S. N. Luke

P. W. Martin

H6-24

T3-04

D. R. Pyzel

T4-04

D. G. Saueressig

H6-24

CWC Operating File

T4-04

Lockheed Martin Services, Inc.

Central Files

B1-07

DPC

H6-08

EDMC (2)

H6-08

Distr-1 
DOE/RL-99-46, Rev. 0

07/99

DISTRIBUTION

MSNN

This page intentionally left blank.

Distr-2 